Gazi University
Journal of Science
http://dergipark.gov.tr/gujs

\title{
Analysis of the Educational Environments of Konya Science Center in the Context of Space and Technology
}

\author{
Asiye SIRTKAYA UZUN ${ }^{1,(1)}$, Sebnem ERTAS BESIR ${ }^{2 *}$ (D) \\ ${ }^{1}$ Karadeniz University, Faculty of Architecture, Department of Interior Architecture, Trabzon, Turkey \\ ${ }^{2}$ Akdeniz University, Faculty of Architecture, Department of Interior Architecture, Antalya, Turkey \\ Highlights \\ - It focuses on the design problem of the science center. \\ - The venue setup of science centers in Turkey are studied. \\ - The science center is examined in relation to space and technology.
}

Article Info

Received: 27 Sep 2020

Accepted: 18 Dec 2021

Keywords

Science center

Interior architecture

Technology

Space

\begin{abstract}
Recently, informal education environments that support existing schools have been created due to changing educational needs. Science Centers, which are one of the informal education environments, have also started to become widespread in our country in recent years and all this has brought about the design problem of these buildings. The aim of the study is to reveal how the interiors of science centers should be constructed within the context of the relationship between space and technology. As a result, while the study is expected to guide the interior architects for the science center designs, the exhibition areas should be highlighted as the focus point as an educational area. In addition, interactive exhibition dec dec which can be tried by touching and playing between space and technology themed exhibition areas in science centers for students are among the places that make the greatest contribution in terms of informal education. In this direction, the educational units of Konya Science Center are examined.
\end{abstract}

\section{INTRODUCTION}

The most effective way to ensure sustainability in education is to ensure that the individual experiences the knowledge acquired. The insufficiency of formal education in ensuring such sustainability has brought about the necessity of informal education areas [1]. In informal learning environments, students' learning by experiencing and interacting with their peers also helps to the formation of the feelings of self-esteem and self-confidence in students. Informal education environments also provide individuals with the ability to bring solutions to the problems that they will encounter in daily life [2].

According to Falk, informal education is defined as free-choice education and it is explained as learning that regularly directs itself in environments such as national parks, nature centers, nature-history museums, zoos and aquariums, science centers, print and electronic media. Braund and Reiss [3] also cited science museums, science centers, zoos, botanical gardens, parks, practice centers, industrial and commercial facilities as examples of informal education environments. In the 21st century, while schools are described as institutions that are boring, outdated and do not appeal to the scientists of the future, informal educational environments are considered as exciting, engaging and refreshing educational environments [4-6]. With the inclusion of informal education in formal education, the learning experience is expected to be meaningful and realistic [7,8]. Informal learning environments such as science centers, museums, energy parks, planetariums serve to integrate formal education with informal education [9].

In this context, unlike schools as formal education environments, science centers support the development of self-confidence by allowing children to freely choose the subject they want to learn. Therefore, science 
centers are designed as environments that inspire visitors and contribute to their personal development with their interesting spaces that encourage free and independent movement. While science centers support lifelong education, their primary target group is children and young people [10-15].

Science centers are institutions that bring people together with science as both discovery and technology centers which have become widespread in recent years. While science centers emphasize the importance of science, they also allow us to question, think, and explore by accessing people of all ages and cultures. During the visit to the science center, visitors can experience a practical exhibition in person. For example, they can let the water run by rotating the wheel of the suction and force pump, which is the first water transport mechanism, or experience arm movements that allowed the person who made the first flight attempt to glide in the air. With all these experiences, visitors can look at the universe through the eyes of a scientist, take the first steps of the scientific thinking style, and thus the interest in the user towards science and technology is aroused [16].

In these centers, students accompanied by trained employees and their teachers find the opportunity to make observations in exhibition venues where a variety of topics are explained, and they seek answers to the questions in their minds and make their knowledge permanent [17,18].

In recent years, science centers have started to become widespread in Turkey; however, a design problem related to the buildings has arisen. It is important how the spaces designed in the buildings will be perceived by the user. The perception desired to be left in the user should be considered, and arrangements that will contribute positively should be made by considering the purpose for which space will be used. Therefore, it can be said that centers are established by developing various themes. In the study, since it is the first center sponsored by TUBITAK in Turkey and they especially contain interactive exhibition venues, the educational environments in Konya Science Center were examined in technology, science and space relationship aspects.

\section{SCIENCE CENTERS IN TURKEY}

Today in Turkey, numerous science centers have been established with the initiatives of municipalities, universities and TUBITAK. An important issue when establishing science centers is the size of the area where the science center building will be located. Although there are no definite limits on this issue, the city where the science center will be established should have enough space in line with the population density and standards set by TUBITAK [19]. In this regard, the science centers established in our country, those established before 2010 and the science centers established with the support of TUBITAK after 2010, the spatial properties and square meters of the centers are briefly listed in Table 1.

Table 1. Science Centers in Turkey

\begin{tabular}{|c|c|c|c|c|c|}
\hline \multicolumn{3}{|c|}{ Science Centers Established Before 2010} & \multicolumn{3}{|c|}{$\begin{array}{l}\text { Science Centers Established with the Support } \\
\text { of TUBITAK After } 2011\end{array}$} \\
\hline Name & $\begin{array}{l}\text { Foundation } \\
\text { Year and } \\
\mathrm{m}^{2}\end{array}$ & $\begin{array}{l}\text { Spatial } \\
\text { Properties }\end{array}$ & Name & $\begin{array}{l}\text { Foundation } \\
\text { Year and } \\
\mathrm{m}^{2}\end{array}$ & Spatial Properties \\
\hline $\begin{array}{l}\text { Feza Gürsey } \\
\text { Science } \\
\text { Center } \\
\text { (Ankara) }\end{array}$ & $\begin{array}{l}1993 \text { year } \\
\text { and } 2,000 \\
\mathrm{~m}^{2} \text { closed } \\
\text { area }\end{array}$ & $\begin{array}{l}\text { - It is the first } \\
\text { Science center } \\
\text { in Turkey. } \\
\text { - } 50 \text { Exhibition } \\
\text { Units, } \\
\text { - Science } \\
\text { Workshops, } \\
\text { - 7D Cinema, } \\
\text { - Science } \\
\text { Theater } \\
\text { are available. }\end{array}$ & $\begin{array}{l}\text { Konya } \\
\text { Science } \\
\text { Center } \\
\text { (Konya) }\end{array}$ & $\begin{array}{l}2014 \text { year } \\
\text { and } 26,250 \\
\mathrm{~m}^{2} \text { closed } \\
\text { area }\end{array}$ & $\begin{array}{l}\text { - } 8 \text { exhibition } \\
\text { venues } \\
\text { - Planetarium } \\
\text { - Workshops } \\
\text { - Seminar hall } \\
\text { - Library } \\
\text { - Observatory } \\
\text { - Laboratories } \\
\text { - Store } \\
\text { - Cafeteria }\end{array}$ \\
\hline
\end{tabular}




\begin{tabular}{|c|c|c|c|c|c|}
\hline $\begin{array}{l}\text { Bayrampaşa } \\
\text { Science } \\
\text { Center } \\
\text { (Istanbul) }\end{array}$ & $\begin{array}{l}2008 \text { year } \\
\text { and } 600 \mathrm{~m}^{2} \\
\text { closed area }\end{array}$ & $\begin{array}{l}\text { - } 4 \text { Laboratories } \\
\text { (Chemistry, } \\
\text { Biology, } \\
\text { Science- } \\
\text { Technology, } \\
\text { Physics) } \\
\text { - Mathematics } \\
\text { Workshop } \\
\text { - Library } \\
\text { - Guesthouse }\end{array}$ & $\begin{array}{l}\text { Bursa } \\
\text { Science and } \\
\text { Technology } \\
\text { Center } \\
\text { (Bursa) }\end{array}$ & $\begin{array}{l}2014 \text { year } \\
\text { and } 11.000 \\
\mathrm{~m}^{2} \text { closed } \\
\text { area }\end{array}$ & $\begin{array}{l}\text { - Exhibition } \\
\text { venues } \\
\text { - Laboratories } \\
\text { - Workshops } \\
\text { - Planetarium } \\
\text { - Cafeteria } \\
\text { - Store }\end{array}$ \\
\hline $\begin{array}{l}\text { Mevlana } \\
\text { Community } \\
\text { and Science } \\
\text { Center (Izmir) }\end{array}$ & $\begin{array}{l}2010 \text { year } \\
\text { and } 2.500 \\
\mathrm{~m}^{2} \text { closed } \\
\text { area }\end{array}$ & $\begin{array}{l}\text { - Basic Sciences } \\
\text { Exhibition } \\
\text { Venue } \\
\text { - Fossil Science } \\
\text { and Natural } \\
\text { History } \\
\text { Exhibition } \\
\text { Venue } \\
\text { - History of } \\
\text { Science and } \\
\text { Philosophy } \\
\text { Exhibition } \\
\text { Venues }\end{array}$ & $\begin{array}{l}\text { Kocaeli } \\
\text { Science } \\
\text { Center } \\
\text { (Kocaeli) }\end{array}$ & $\begin{array}{l}2015 \text { year } \\
\text { and } 8.500 \\
\mathrm{~m}^{2}\end{array}$ & $\begin{array}{l}\text { - Exhibition } \\
\text { venues } \\
\text { - Workshops } \\
\text { - Laboratories } \\
\text { - Seminar hall } \\
\text { - Library } \\
\text { - Research offices } \\
\text { - Cafeteria }\end{array}$ \\
\hline $\begin{array}{l}\text { Gaziantep } \\
\text { Planetarium } \\
\text { and Science } \\
\text { Center } \\
\text { (Gaziantep) }\end{array}$ & $\begin{array}{l}2010 \text { and } \\
3.500 \mathrm{~m}^{2} \\
\text { closed area } \\
1.500 \mathrm{~m}^{2} \\
\text { open area }\end{array}$ & $\begin{array}{l}\text { - Planetarium } \\
\text { - Various } \\
\text { Workshop } \\
\text { Spaces }\end{array}$ & $\begin{array}{l}\text { Elazı̆̆ } \\
\text { Science } \\
\text { Center } \\
\text { (Elazığ) }\end{array}$ & $\begin{array}{l}2015 \text { year } \\
\text { and } 2.700 \\
\mathrm{~m}^{2}\end{array}$ & $\begin{array}{l}\text { - Exhibition } \\
\text { venues } \\
\text { - Planetarium } \\
\text { - 3D Cinema } \\
\text { - Science drama } \\
\text { venue } \\
\end{array}$ \\
\hline $\begin{array}{l}\text { Science } \\
\text { Experiment } \\
\text { Center and } \\
\text { Sabanc1 Space } \\
\text { House } \\
\text { (Eskişehir) }\end{array}$ & $\begin{array}{l}2012 \text { year } \\
\text { and } 2.751 \\
\mathrm{~m}^{2}\end{array}$ & $\begin{array}{l}\text { - Exhibition } \\
\text { Units } \\
\text { - Space House } \\
\text { (Scientific } \\
\text { Shows Hall) } \\
\text { - Workshops }\end{array}$ & $\begin{array}{l}\text { Kayseri } \\
\text { Science } \\
\text { Center } \\
\text { (Kayseri) }\end{array}$ & $\begin{array}{l}2016 \text { year } \\
\text { and } 10.000 \\
\mathrm{~m}^{2}\end{array}$ & $\begin{array}{l}\text { - Exhibition } \\
\text { venues } \\
\text { - Workshops } \\
\text { - Planetarium } \\
\text { - Seminar hall } \\
\text { - Library }\end{array}$ \\
\hline
\end{tabular}

In this regard, in Feza Gürsey Science Center, which was established in Ankara in 1993, there is an exhibition area with approximately 50 exhibition units in various disciplines. There are also science demonstrations in the center in which various experiments on physics and chemistry are conducted at certain times (Figure 1). There are also periodical events under the titles of science camps, science workshops and science observations in various fields. The Science Center also offers visitors the opportunity to watch 3D and films with special effects with 7D cinema with a capacity of 12 people for entertainment purposes. It also hosts special day celebrations.

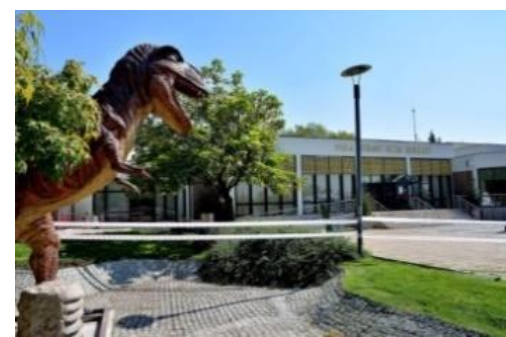

Figure 1. Feza Gürsey Science Center [20] 
Bayrampaşa Science Center was founded in 2008 by Bayrampaşa Municipality. In this center, they have realized many projects with the support received from TUBITAK and various institutions. Apart from interactive exhibitions, workshops and laboratories are prioritized in Bayrampaşa Science Center. It includes chemistry, physics, science-technology and biology laboratories and a mathematics workshop (Figure 2).

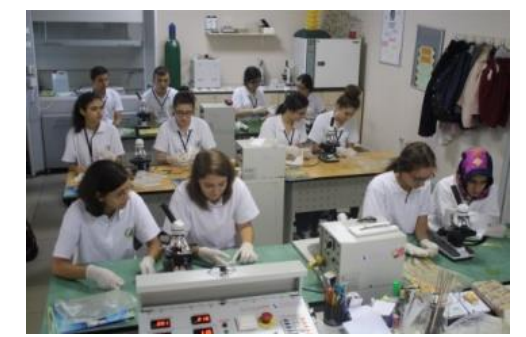

Figure 2. Bayrampaşa Science Center [21]

Workshops are carried out in groups with an average of 12 people. Apart from these workshops, individual research projects are conducted with students in the science center, which organizes summer camps and science festivals in different disciplines. They have been successful in national and international platforms with the projects carried out so far. There is also a rich library and a guesthouse.

Mevlana Community and Science Center was established in 2010 in Izmir. There are venues for Basic Sciences, Fossil Science, Natural History, History of Science and Philosophy. In the Fossil Science Exhibition Hall opened in 2015, changes that have occurred on earth since 540 million years ago are illustrated. Participants can take part in these training programs by filling out an application form via the website or at the center. In certain periods, workshop activities are carried out in the fields of chemistry, physics, biology, robotics, astronomy, paleontology. The predominant target group is middle and high school students. Besides, science-society projects have been implemented since 2010 with the support received from TUBITAK, UNICEF and different institutions (Figure 3).

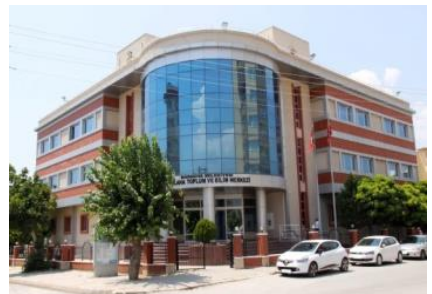

(a)

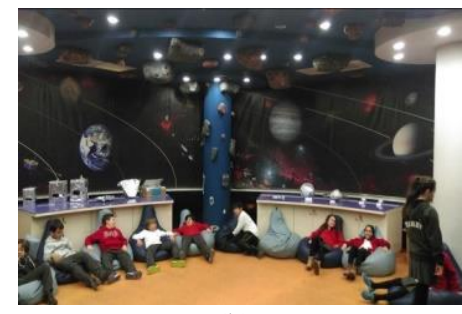

(b)

Figure 3. Mevlana Community and Science Center; (a) the entrance, (b) astronomy education [22]

The Gaziantep Planetarium and Science Center, which was founded in 2010, also includes workshops, a planetarium and permanent and temporary exhibition halls. In the exhibition area, there are basic science, astronomy and space themed exhibition units that appeal to all age groups. Figure 4 indicates the exterior view of the Gaziantep Science Center building and the basic science exhibition area (Figure 4).

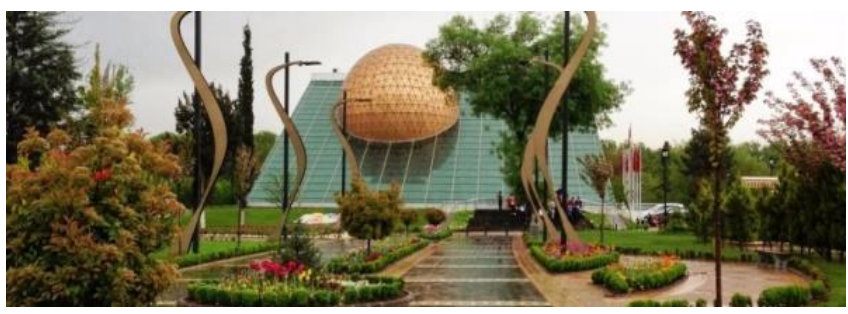

(a)

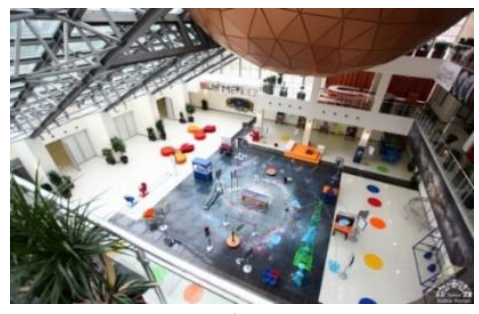

(b)

Figure 4. Gaziantep Planetarium and Science Center; (a) the exterior view of the building, (b) basic science area [23] 
Physics, chemistry, biology, art, robotics and space-themed workshops and laboratory events are regularly held within the science center for pre-school, primary and high school students. Periodically, some workshop activities are also held with family participation for pre-school and primary school students. Workshops are limited to about 16 people. Apart from all these, periodically, science festivities, indoor and outdoor workshops and sky observations open to the public are held on various subjects. The planetarium has nature and space themed shows covering different age groups. The planetarium's dome is 10.6 meters in diameter and has a capacity of 77 people.

The Science Experiment Center and Sabancı Space House established in 2012 in Eskişehir have sound, pressure, earth, handcraft and attention, optics, balance-mechanics and other basic science-themed exhibition units. Animatronic dinosaur section, three-dimensional cinema room, Turkish-Islamic Scholars section and speaking scientist portraits are also available. Natural sciences, social sciences and humanities, art workshops and game shows and competitions are organized for science festivities. The Planetarium has a capacity of 96 people, and demonstrations on space and astronomy, astronomy discussions without age limit, and special training in astronomy for teachers are available. In Figure 5, there is a visual from the science center building, the planetarium and the exhibition area.

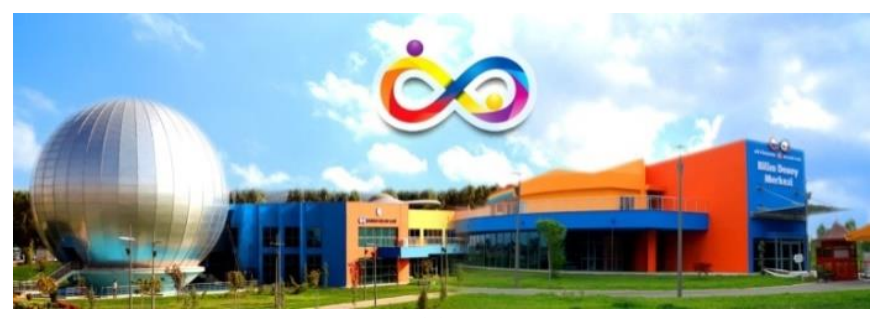

(a)

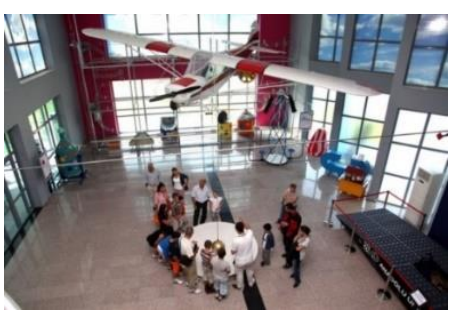

(b)

Figure 5. Eskişehir Science Experiment Center; (a) the planetarium, (b) the exhibition area [24]

In line with the decision taken by the Supreme Council of Science and Technology (BTYK) in 2011, the first science center supported by TUBITAK was opened in Konya in 2014 as Konya Science Center. Konya Science Center is an exemplary green building with a Leed certificate with its wind power plant and solar panels. Konya Science Center consists of three separate units, which are the planetarium, navigation and observation tower connected to the main building by bridges. In the main building, there are exhibition areas separated according to their themes, workshops, laboratories, seminar hall, library, store and cafeteria units [25] (Figure 6).

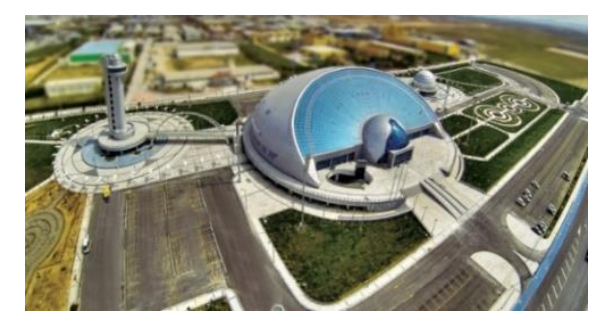

Figure 6. Konya Science Center [26]

In 2014, Bursa Science and Technology Center started to operate. There are approximately 270 exhibition units in 14 different venues. Educational areas, workshops and laboratories for various scientific disciplines, simulation devices, planetarium, cafe-restaurant, and stores are available. In certain periods, science festivities, some of which include accommodation in a tent within the center, are also organized. Opportunities are also offered for special celebrations such as birthdays (Figure 7). 


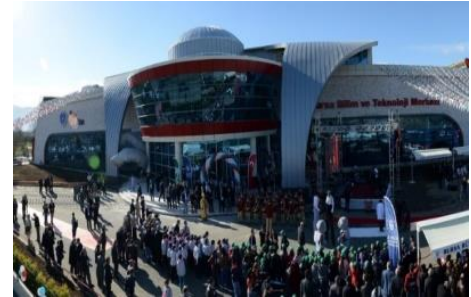

(a)

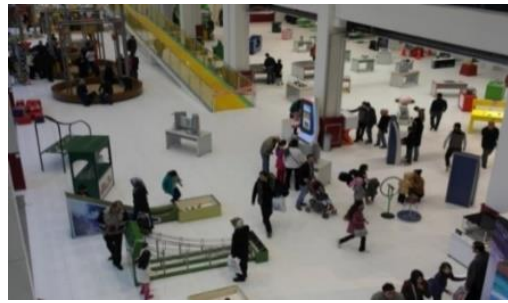

(b)

Figure 7. Bursa Science Center; (a) the external view of the building, (b) the exhibition area [27]

Kocaeli Science Center was established on an area of 8,500 square meters on the premises of Seka Paper Factory, which was built in 1934 as the largest industrial transformation project in Turkey. In Kocaeli Science Center, there are exhibition areas with approximately 250 experimental setups. There are workshops and laboratories where scientific events are held, a scientific stage where scientific shows and interviews are held, research offices, a library, and a science cafe (Figure 8).

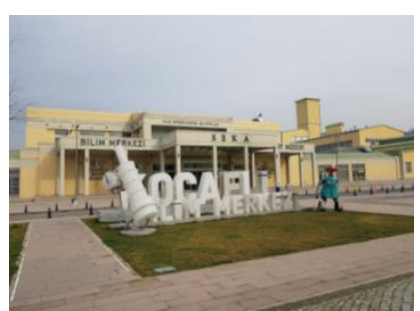

(a)

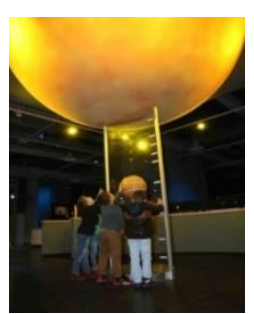

(b)

Figure 8. Kocaeli Science Center; (a) the entrance of the building, (b) the exhibition area [28]

Another center established in 2015 is Elazı $\breve{g}$ Science Center. In addition to the exhibition areas with 1,300 square meter area, workshop and planetarium, there is a 3D cinema hall with a capacity of 50 people and a science drama area where science shows are held. Interviews, training programs and science festivals are organized at certain times (Figure 9).

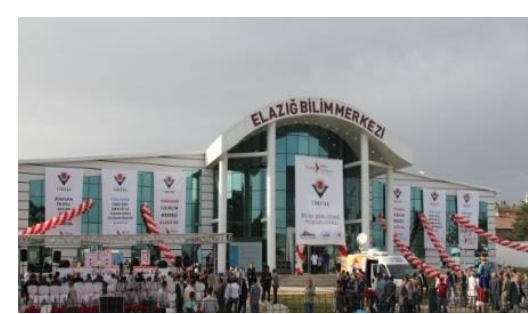

(a)

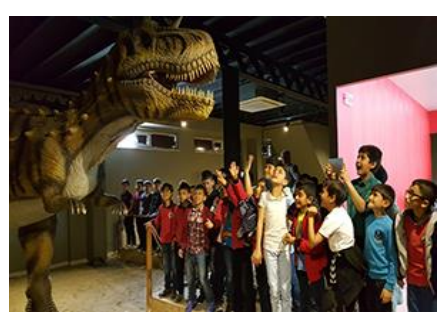

(b)

Figure 9. Elazı ğ Science Center; (a) the external view of the building, (b) the exhibition area [29]

In 2016, Kayseri Science Center became operational. There are exhibition galleries indoors and outdoors. In the planetarium with a 14-meter dome radius and a capacity of 109 people, astronomy training is provided as well as space-themed shows. There are three workshops with special programs for all age groups with robotics, sciences and art themes. There is a seminar hall where training and interviews are held and a library. Various basic sciences and space themed exhibitions are displayed in the exhibition area. Besides, there is a discovery tower section in the exhibition area where the first science foundations are laid for children aged 1-6. Kayseri Science Center also has a cafeteria and a store selling scientific materials and souvenirs (Figure 10). 


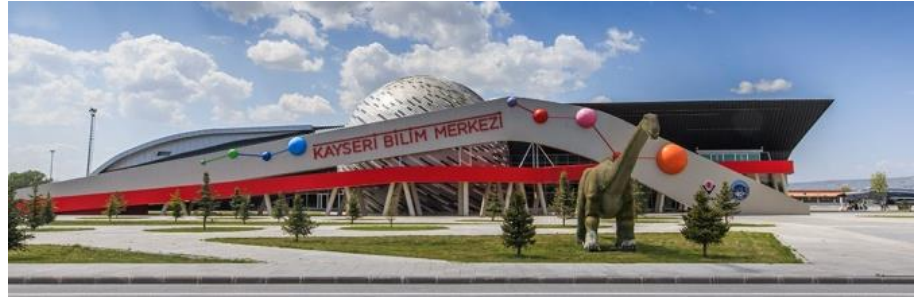

(a)

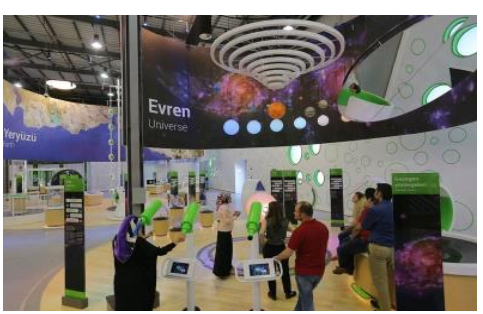

(b)

Figure 10. Kayseri Science Center; (a) the external view of the building, (b) the exhibition area [30]

\section{METHODS AND MATERIAL}

\subsection{Konya Science Center and Sultans of Science Exhibition}

For the call issued by TÜBİTAK in 2008, Konya Science Center, built on an area of approximately 100,000 $\mathrm{m} 2$ with $26,248 \mathrm{~m} 2$ closed area, $6,100 \mathrm{~m} 2$ of exhibition space and 1,000 $\mathrm{m} 2$ of educational units, was opened in Turkey as the first science center and a planetarium with international qualities in 2014. Konya Science Center is located on the Ankara-Konya highway, $25 \mathrm{~km}$ from the city center, and close to Konya Airport. Besides, the high-speed train junction will be built close to the center, which will allow easy access for domestic and foreign visitors [31,32] (Figure 11).

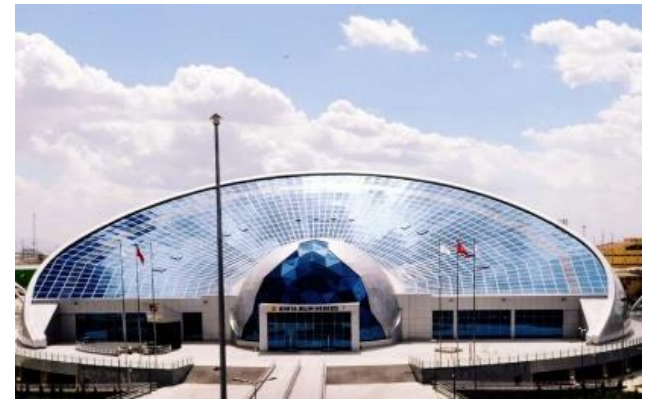

Figure 11. Konya Science Center front facade [33]

The building consists of three separate buildings with the planetarium and the observation tower connected to the main building by bridges. Konya Science Center is a four-story building consisting of a basement, ground floor, first and second floor. In the main building, there are exhibition areas, workshops and laboratories, congress halls, library, store, cafeteria and other service units. The entrance and parking areas are designed separately, considering that the visitors will arrive at the center individually or by bus as a group.

At the other stage of the study, considering the characteristics of all the exhibition areas, the Sultans of Science exhibition area, which is the largest square meter and the most comprehensive exhibition area with multiple themes, was designated as the working area. Thus, students were observed against the physical characteristics of the exhibition areas, which are an important educational environment of science centers. Sultans of Science in the exhibition area; water transport systems, astronomy, chemistry, medicine and surgery, optical science, mathematics, and architecture, aviation, science, and thirty-five explorers and their discoveries of the theme exhibition of the famous Muslim mechanism. As can be seen in Figure 12, a certain fiction cannot be found in the layout of the exhibition units. In each exhibition section, there are written, oral and digital explanations with simple explanations that will make it possible to understand the topic. 


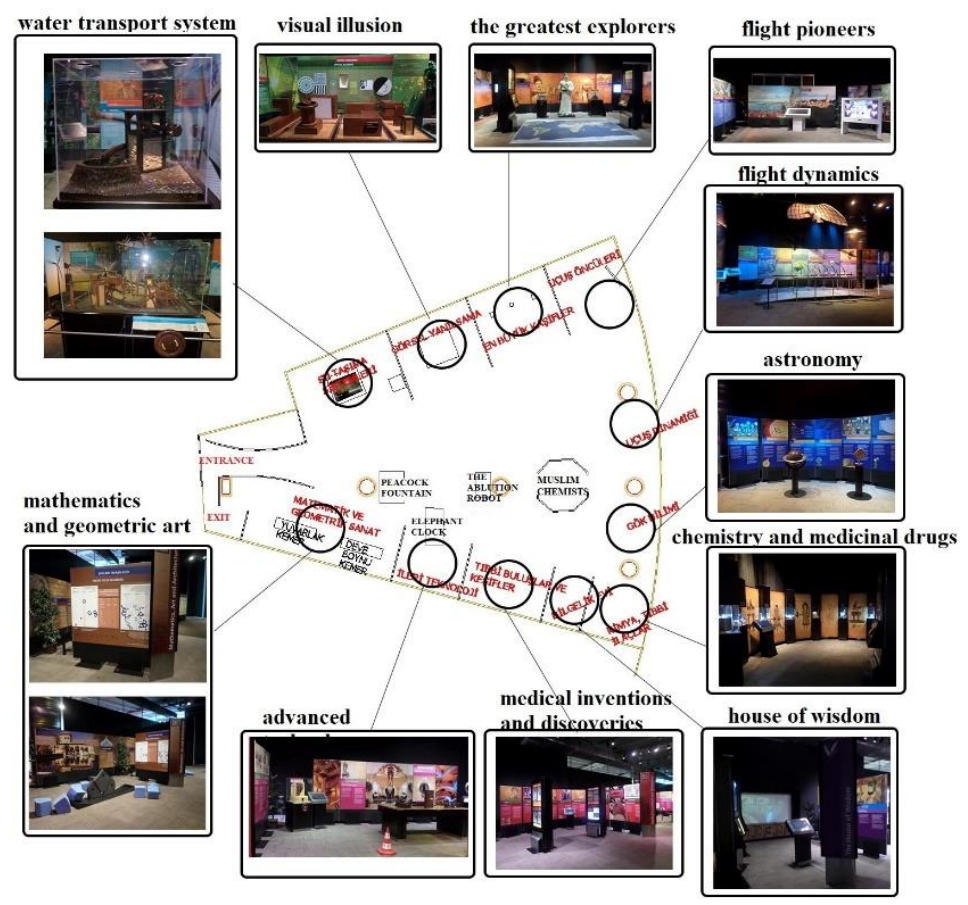

Figure 12. Sultans of Science exhibition assemblies [34]

\subsection{Determination of the Subject Group}

Science centers are informal educational areas that appeal to all ages, but the main target users are students. For this reason, students were preferred as the subject group in the study. Konya Science Center, the space concerned with the preparation and operation of the plans and detailed examination of information and guidance from the officials, school groups, such as observation and interview with the necessary permits for the work they do with reference Konya Metropolitan Municipality, Director of the Center for science and Hamdi is provided by Sertaç NOMAD black root. School visits to the Konya Science Center are carried out by appointment system; the future of which schools and which age group is determined one week in advance. The determination of the subject group for this study took place in two stages. High school students who were in the abstract procedural period were selected as the subject group because their perceptions were more developed in the first stage. However, due to their lack of interest in the exhibition areas, the study with this group of subjects was terminated. After that, both the conducted research and the guidance of the employees of the Konya Science Center were accepted as subjects in the 10-13 age group. In this regard, 15 students from Konya Seydişehir Primary School and Konya Gazi Primary School were selected as observation groups through the permits obtained by the Konya Science Center. A smaller age group was not preferred in terms of observing their behavior in the exhibition area and achieving healthier results. The age and gender of the subjects are shown in Table 2. 15 Students were observed in the Sultans of Science exhibition area.

Table 2. Information about the observed students

\begin{tabular}{|l|l|l|}
\hline Subject No & Age & Gender \\
\hline 1 & 11 & Male \\
\hline 2 & 12 & Female \\
\hline 3 & 12 & Female \\
\hline 4 & 12 & Male \\
\hline 5 & 10 & Female \\
\hline 6 & 11 & Male \\
\hline 7 & 12 & Female \\
\hline 8 & 10 & Male \\
\hline 9 & 12 & Male \\
\hline 10 & 13 & Female \\
\hline
\end{tabular}




\begin{tabular}{|l|l|l|}
\hline 11 & 12 & Female \\
\hline 12 & 12 & Female \\
\hline 13 & 10 & Female \\
\hline 14 & 10 & Female \\
\hline 15 & 11 & Male \\
\hline
\end{tabular}

\subsection{Methods}

Science centers are an important informal educational structure that appeal to different age groups. Especially in recent years, it has been being built in Turkey in different concepts and sizes depending on both the population and the need. However, the fact that the equipment used in the centers consists of technological tools and has a variety of functions in it reveals the importance of the design process. This study aimed to determine the scientific and technological characteristics of the educational environments of the Konya Science Center, which received the support of the first TUBITAK in Turkey, and to determine the positive and negative design decisions related to the informal education environments located in science centers through them. In this direction, the work consists of two stages. Firstly, a 5-month detection study was carried out; The needs of the educational environments were determined and the physical characteristics of all the spaces were revealed. At the second stage, students of different age groups who experienced the sultans of Science serge area, which belongs to an important place among these places, were observed dec the serge spaces, which belong to an important place among these places. December February 16-17, for two days, students aged between 10-13 Dec observed to experience the Sultans of Science exhibition area. The observations were made by 3 internal medicine senior students and the responsible author. In the Konya Science Center, Sultans of Science exhibition area, visitors are released after general introductions are made for each exhibition area, accompanied primarily by a guide. However, in the study, in order to get more objective results, the group to be observed was not consulted in advance, and the students were provided with a completely free tour. In the observations made in the first working group, it was observed that the students did not move naturally during the video recording. Therefore, observations can be used for voice recording, photographing, identification on sketches, etc. it is registered with the materials.

\section{FINDINGS}

\subsection{Physical Characteristics of the Educational Environments of the Konya Science Center}

Considering the educational environments of the Konya Science Center, it consists of exhibition units, educational and cultural units and the planetarium. While there are exhibition areas, workshops and laboratories on the ground floor, exhibition areas, laboratory and library units are on the first floor.

Exhibition Units: There are three types of exhibitions covering an area of 6,100 m2 in Konya Science Center. Digital exhibition areas and permanent exhibition areas related to each other with similar subjects are considered together. Considering the changing of exhibition units placed in the exhibition areas in case of aging and losing their appeal, these areas are designed as flexible and divisible spaces. The life span of an average exhibition unit is calculated as five to seven years. All of the exhibition units are interactive and have a structure that can be tried by touching and playing. Six of the exhibition areas consisting of seven main themes are located in the interior of the Konya Science Center. These exhibition areas, which are permanent exhibitions, consist of mechanical and digital exhibition units according to the contents of the exhibition setups.

Sultans of Science Exhibition Area (permanent-mechanical): This area is located on the ground floor. In this exhibition area where the history of science is mostly explained, the inventions of Turkish and Muslim scientists are displayed. In this area, there are mostly information-based visual exhibition units with themes such as flight/aviation, mathematics-arts-architecture, astronomy, medicine and surgery section, optics, chemistry, and buoyancy of water. As the entrance and exit directions of the exhibition area are not clear, direction is provided with arrow-shaped signs as shown in Figure 13. 


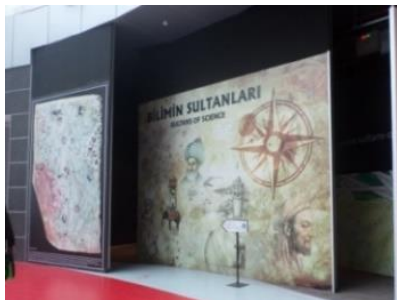

(a)

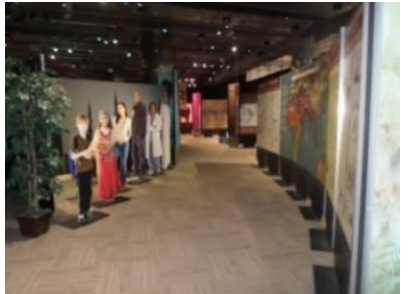

(b)

Figure 13. Sultans of Science exhibition area entrance; (a) entrance of the exhibition area, $(b)$ entrance hole [34]

Carpet tiles are used on the entire floor of the exhibition area. Units on different topics are separated by boards with written and visual information on them. Lighting is in the form of general illumination and spotlights on rails on the ceiling directed at setups (Figure 14).

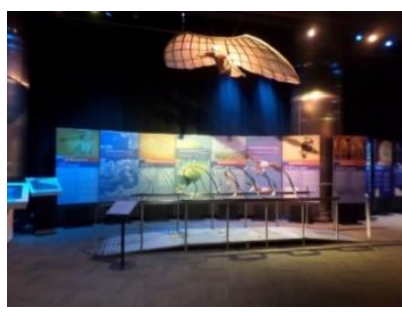

(a)

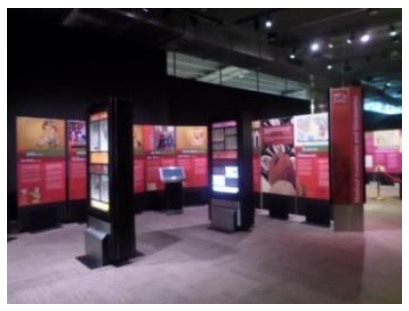

(b)

Figure 14. Sultans of Science exhibition space, exhibition setup; (a) flight dynamics, (b) medical inventions and discoveries [34]

The background walls of the exhibition area are made of plasterboard walls and painted in black, and the ceiling is made up of steel construction, where ventilation ducts and lighting installations are visible.

In Figure 15, there are arch forming elements, which are exhibition units where visitors can try and see the cause-effect relationship and create on their own. Other units are interactive museum exhibition units. There are no direction signs within the exhibition area, except for mandatory exit signs.

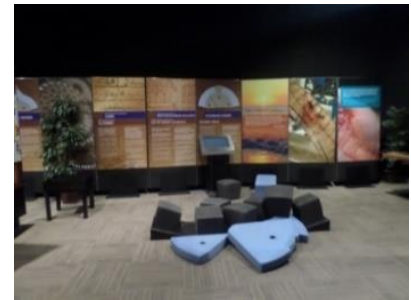

Figure 15. Sultans of Science, mathematics and art exhibition setup [34]

Our Body Exhibition Venue (permanent-digital-mechanical): Our Body exhibition venue is located on the ground floor and can be accessed directly from the entrance area. The entrance is highlighted with text characters and red color (Figure 16).

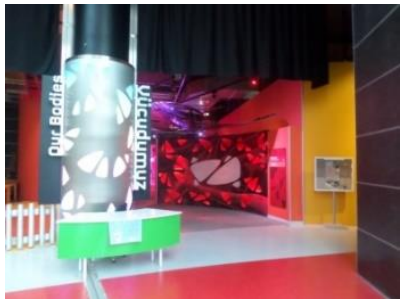

(a)

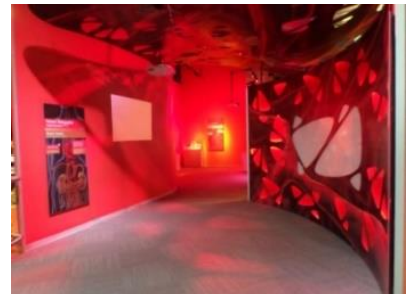

(b)

Figure 16. Our Body Exhibition Venue entrance, (a) entrance of the exhibition area, (b) entrance hole [34] 
31 exhibition units in the exhibition venue are available about the vital systems such as the skeletal system, circulatory system and genetics in our body. The majority of the exhibition units consist of digital interactive exhibition units. Within the exhibition venue, there is Prof. Dr. Aziz Sancar biomedical laboratory used under supervision. The laboratory was opened by Prof. Dr. Aziz Sancar. This laboratory is closed to the general visitor, except visitors with appointments (Figure 17).

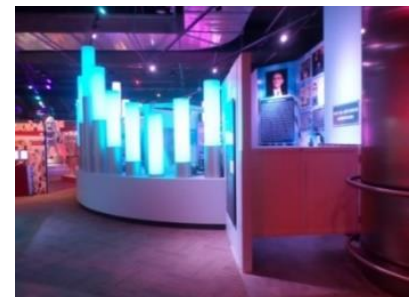

(a)

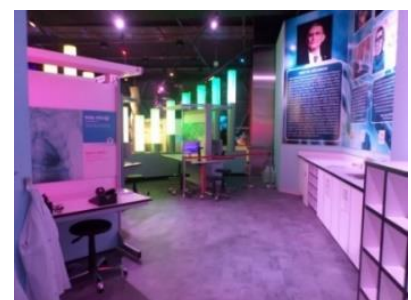

(b)

Figure 17. Prof. Dr. Aziz Sancar Laboratory; (a) entrance of the laboratory, (b) laboratory [34]

The boards that provide information about the exhibition units in the Our Body exhibition venue also serve as lightweight separators. Tile carpet tiles of the same type are used throughout the floor, but darker colored carpet tiles are used to both emphasize and separate some units. In this section, various colors such as red, orange and blue are used on the background walls according to the theme of the exhibition unit. Besides, the appropriate emphasis was made with colored led lamps per the theme (Figure 18).

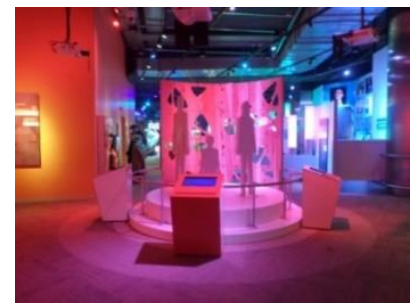

Figure 18. Our Body exhibition venue setup [34]

Immune System exhibition units in Our Body exhibition venue are designed as a separate space in the general area with lightweight separators. To draw attention to this area, elements such as red inclined walls, objects hanging from the ceiling and sound effects are used. When entering the area, natural orientation is provided with inclined walls (Figure 19).

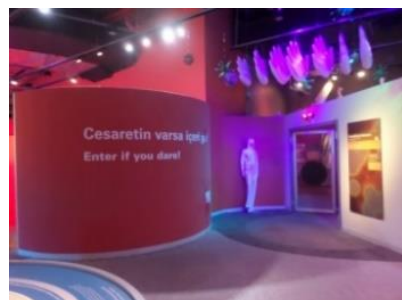

(a)

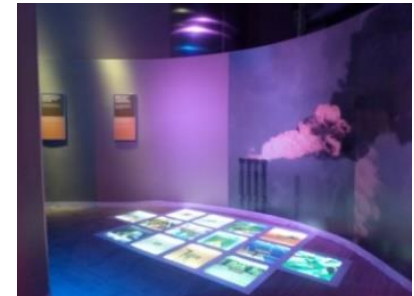

(b)

Figure 19. Immune System exhibition unit; (a) entrance of the unit, (b) inner side of the unit [34]

Our World Exhibition Venue (permanent-digital-mechanical): The exhibition venue, located on the ground floor, contains visual, auditory and tactile exhibition mechanisms in various themes that provide information about our world from the first formation to this time and describe natural disasters, natural energy systems and climates (Figure 20). 


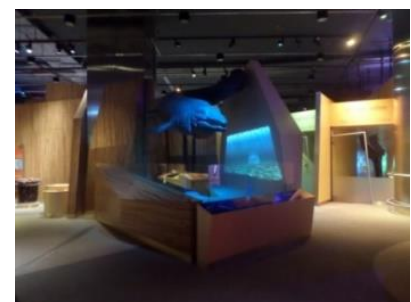

Figure 20. Our World exhibition venue, exhibition unit [34]

The entrance is highlighted with a light separator wall in different colors and forms. In this exhibition venue, like other exhibition areas, a single type of carpet tile is used on the floor. Light separators in different colors and textures are used according to the theme of the exhibition unit. While separators distinguish different exhibition units, they also form the surface of another exhibition unit. Lighting elements that emphasize the exhibition units are used in conjunction with general lighting.

Since the exhibition setups describing the working system of dams and hydroelectric power plants can be operated under the control of the participants, the area where these units are located is covered with PVC coating as a measure against water overflows (Figure 21).
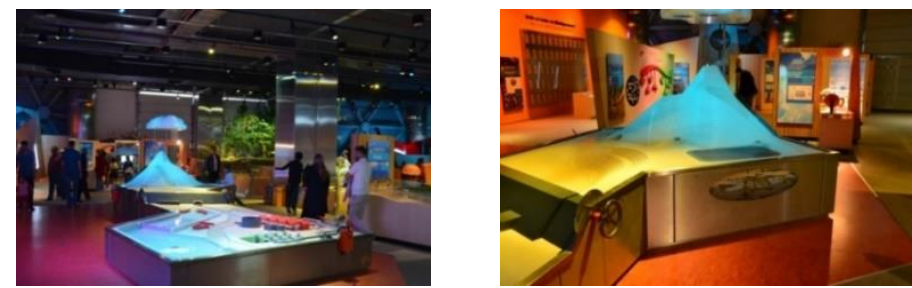

Figure 21. Dam exhibition setup/exhibition unit floor covering [34]

In Our World exhibition venue, indoor spaces where the climates can be experienced are created with plasterboard dividing walls for the exhibition unit with the theme of climates (Figure 22).

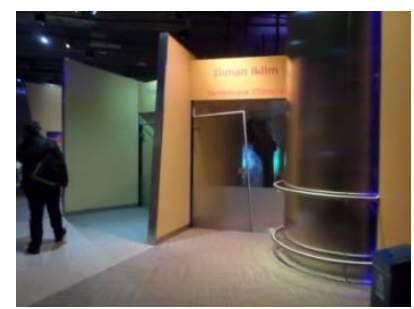

Figure 22. Climates exhibition setup [34]

In this exhibition area, there are digital and mechanical exhibition units as well as visual exhibition areas describing the animals and vegetation living in the geography of our country at the early ages (Figure 23).

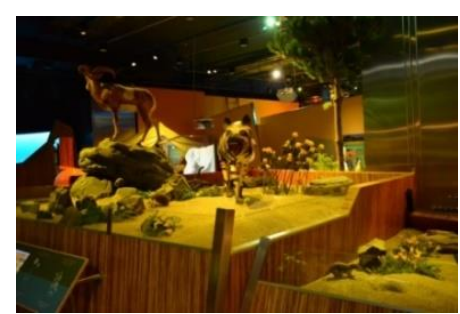

Figure 23. Visual exhibition unit [34]

Our Universe exhibition venue (permanent-digital-mechanical): This exhibition area is located on the ground floor behind the elevators and escalators. Basic information is given about the universe we live in, planets, stars, galaxies and technologies used by humanity during the exploration of space with interactive exhibition mechanisms. There are 21 exhibition setups with the main theme of our location in the universe, observation and exploration and travel to space (Figure 24). 


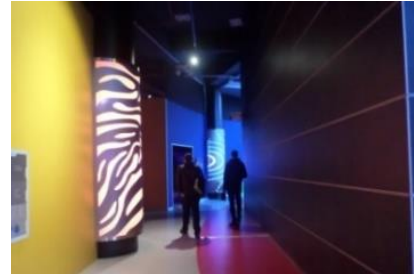

(a)

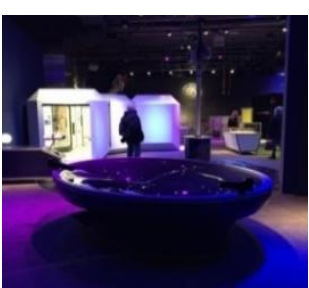

(b)

Figure 24. Our Universe exhibition venue; (a) entrance of the exhibition area, $(b)$ the black hole setup [34]

Our Universe Exhibition venue is enhanced by dark blue wall surfaces and colorful lighting with sky and space themes. In addition to the carpets tiles which are generally used on the floor, PVC material is used to separate the exhibition setups from the circulation area. Besides, there is photo-printed light dividing walls suitable for the subject and supporting the exhibition setup (Figure 25).

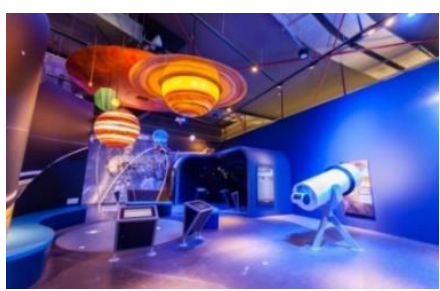

(a)

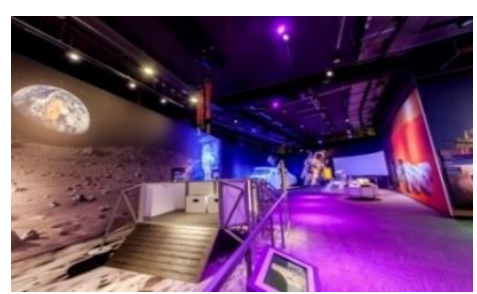

(b)

Figure 25. Space exploration exhibition units; (a) sun and the planet setup, (b) the moon surface setup [34]

The Basic Steps Exhibition Venue (permanent-mechanical): This place, located on the right side of the first floor of the Science Center, consists of three main themes, namely observation, comprehension and physics applications in 27 exhibition units. It is aimed to teach the events occurring in nature in the fields of basic sciences such as mathematics, chemistry, biology, physics by trying and having fun. The entrance part of the exhibition area, which is accessed by escalators or elevators, is highlighted with an effective, color illuminated column on the right side (Figure 26).

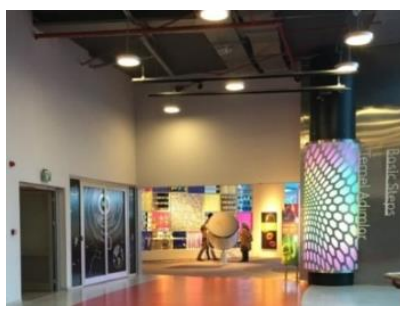

(a)

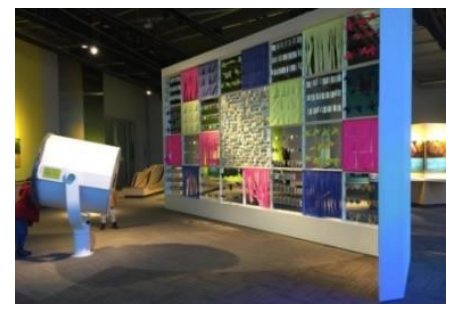

(b)

Figure 26. (a)Basic Steps exhibition area, (b)entrance section [34]

In this exhibition area, no vertical elements or dividers are used. There is a single type of carpet tiles on all floors. The lighting elements are located in the steel construction on the ceiling, and colored led lamps are preferred to increase the appeal in the exhibition units (Figure 27).

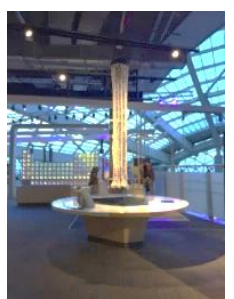

(a)

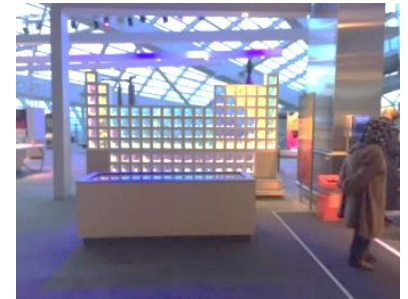

(b)

Figure 27. (a)Basic Steps exhibition venue, (b) Periodic table [34] 
New Horizons exhibition venue (permanent-digital): There are 27 exhibition units in the exhibition venue with themes such as advanced technology, robots, and communication technology. This exhibition gallery is located on the first floor of the center. With the pixel screen that senses the movements of the human body in the entrance area of the exhibition venue, and the colored light panel dressed column at the entrance, it is aimed both to emphasize the entrance section and to arouse interest (Figure 28).

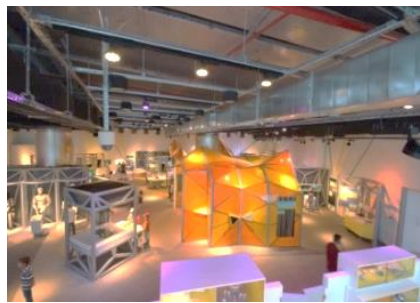

(a)

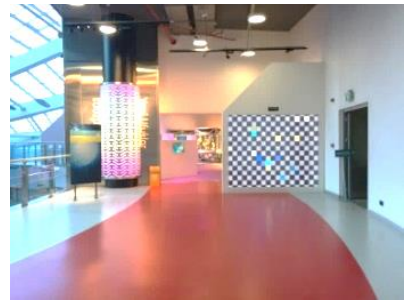

(b)

Figure 28. (a) New Horizons exhibition venue, (b) the entrance of the unit [34]

There are specially separated glass panes for some interactive robots in the New Horizons exhibition venue (Figure 29). Robots in these compartments are used according to the activity program of the science center.

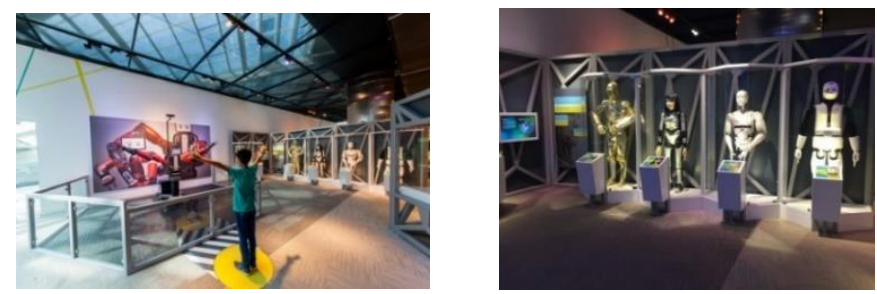

Figure 29. Humanoid robots exhibition unit [34]

There are robots currently used in factories that can interact with visitors in other exhibition units. Within the exhibition area, there is an independent unit whose surfaces are formed by combining different geometric forms under the name of touching tunnel.

Education and Culture Units: In this context, there are workshops and laboratories, conference halls, library and BISTLAB (Istanbul Stock Exchange Laboratory) in Konya Science Center. Workshops and laboratories with training units occupy an area of 1,000 m2. Education units are accompanied by guidance teachers.

Workshops and Laboratories: Workshops and laboratories generally located on the ground floor of the Konya Science Center include life lab, mathematics and technology lab, physics lab, design workshop, waste boiler, Prof. Dr. Aziz Sancar laboratory, curious little inventors, basic steps laboratory and robot arena and BISTLAB.

Design Workshop: It is a workshop where participants can realize their designs in the light of math and physics rules. The workshop on the ground floor is reached by a corridor separate from the entrance hall. Workshop use is based on an appointment system.

Wood is generally used in the productions. Therefore, participants can create their three-dimensional toys using machines that shape wood in the area, which can also be called a small wood workshop. The machines used are highly safe and suitable for children.

Unlike exhibition areas, equipment is used in this area. The working environment is created with mobile tables that are independent of each other. There are cupboards and decorative materials cupboards where the products can be displayed. Wood siding and solid wood materials are used on the floor and the wall. In lighting, general lighting was made with industrial type lamps suitable for the theme of the venue. In addition to the lighting elements, there are decorative elements on the ceiling (Figure 30). 

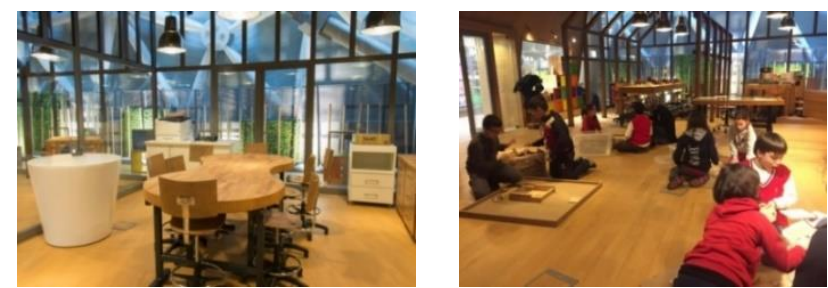

Figure 30. Design workshop workbench and event area [35]

Waste Boiler: It is a workshop where participants experience that waste materials can be recycled by defining new functions for them. Waste boiler workshop is located on the ground floor, and open access is provided from the entrance hall. Light dividers made of waste materials are used in the workshop, which is not designed as a closed space (Figure 31).
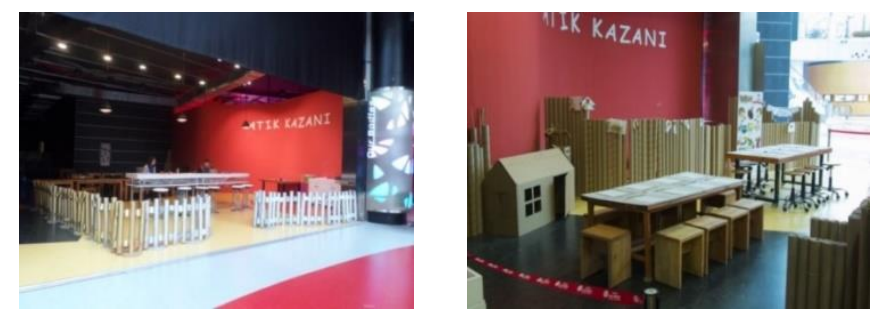

Figure 31. Waste boiler workshop [34]

In this area, space emphasis was achieved with a red curved wall. There are two different colors of PVC coating material on the floor that separates the space from the general space.

Life Laboratory: It is a training area where living things can be examined until the smallest building blocks, the structure of matter and the reactions formed by combining different substances are observed, and all these formations are analyzed with examples from daily life. Access to this training area is controlled. Visitors can register and benefit from this laboratory by an appointment system or when an event announcement is made by the science center. The laboratory, located on the ground floor of the science center, can be accessed through the corridor in the entrance hall. The equipment used in the venue is eightperson fixed work desks, mobile stools and material cabinets. The light-colored PVC coating material is used on the floor. The venue is provided with a sense of movement through different color transitions used on the walls. In this venue, general lighting is provided with recessed spots and decorative lighting elements used in suspended ceilings.

Mathematics and Technology Laboratory: It is the laboratory section where mathematics, which is the basis of shapes and engineering, is interpreted with a different and entertaining perspective and combined with technology, and participants can design their robots. The laboratory is on the ground floor, and it is used in a controlled fashion per the appointments or activities determined by the science center (Figure 32).
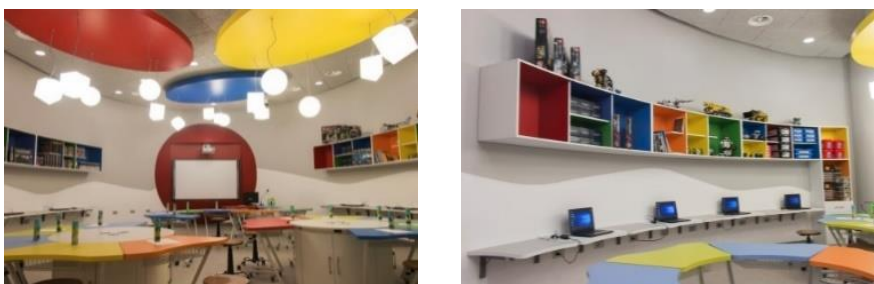

Figure 32. Mathematics and technology laboratory [36]

In the venue designed in a circular form, light-colored PVC coating material is used on the floor, while the walls are coated with a curvaceous grayscale color transition paint. In the ceiling, there are circular decorative panels in red, yellow, blue, colors in line with the space form. The lighting of the venue is provided in the form of general lighting with decorative lighting elements. Venue fittings include multicolored modular desks that can be used in different forms, movable stools, and cabinets where materials used in the class are stored and exhibited, and a smart board. 
Physics Laboratory: It is the education area where participants acquire the knowledge on how physics is used in the field of engineering with the help of small mechanism models prepared by themselves. It is the laboratory where interdisciplinary studies such as astronomy, chemistry, biology and mathematics are carried out, not just physics. It is located on the ground floor of the science center. It is open to visitor use per the programs. In physics laboratory equipment, the desks are arranged in a row in class order and consist of modular tables. There are a material cabinet and a smartboard with a sink and a work desk inside. The light-colored PVC coating material is used on the floor. The walls are designed with yellow color tone paint. The ceiling is a suspended ceiling, and general lighting is provided with recessed spots and decorative lighting elements in the form of an atomic nucleus (Figure 33).
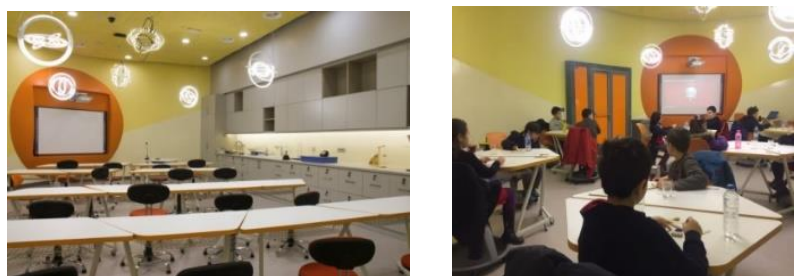

Figure 33. Physics laboratory [37]

Curious Little Inventors: It is the workshop where children in the preschool age group are taught the basics of science by using concrete materials. The workshop, which is open to visitors within the programs, is located on the ground floor of the science center.

Space is divided into two as a fairy tale corner and experiment area with different equipment and floor material. In the corner of the fairy tale, there is carpet coating in earth color tones on the floor. It contains libraries, colored fabric pouffes and smart wooden equipment, which are also used for separation purposes. In the experiment area, there are desks and chairs suitable for preschool child ergonomics. Tables used are not suitable for different combinations as they are star shaped. There is also a small kitchen with materials to be used in events. Light blue PVC coating material was used on the floor in the workshop section. Shapes in blue colored tones are on the walls throughout the space. The ceiling is a blue suspended ceiling, and general lighting is provided with recessed spotlights and decorative lighting elements.

Planetarium: The planetarium, also known as the Planetary House, is a showroom where space-related shows involving various natural phenomena are projected in the dome-shaped ceiling, which also serves as a curtain. Its difference from a cinema is that it grasps the viewer in the show because of the more realistic images and the form of the venue. Konya Science Center planetarium is in the form of a full globe with a diameter of $14 \mathrm{~m}$ and a capacity of 100 people. This venue is accessed by the corridor leaving the entrance hall and then by the bridge. The entrance and exits of the showroom of the planetarium with an entrance hall are provided through separate doors. Apart from the dome ceiling forming the curtain, the walls are covered with fabric, while the floor is carpeted in the feature of a classic movie theater. The seats are also covered with fabric in the form of a cinema seat with movable back.

\subsection{Evaluation of the General Behavior of Students in the Sultans of Science Exhibition}

The observation study was conducted on February 16-17, 2019 without guidance and information in order to accurately determine the behavior of students in the exhibition area. In order for students to be comfortable, it was said that the observation team would experience the exhibition area with them within the knowledge of the guidance teachers and classroom teachers, and the student to be observed was not informed that it would be observed in advance. In the first trial study, it was seen that the student could not act comfortably when he was given the information that he would be observed. Therefore, observers; without noticing what they were watching, they recorded every movement and feeling of the student they were observing, pretending to study the devices themselves.

On the day, 12-13-year-old students were accompanied by guides on trips to the science center within the framework of their programs. Later, students were observed by ensuring their free movement in the Sultans of Science exhibition area. On the second day of the study, after the guided tours of the 10-12-year-old 
students, their free movement was ensured in the Sultans of Science exhibition area and the students were observed in this area. Observer comments were evaluated in the observation forms prepared for 15 students, and the results from the general behavior of the subjects are as follows:

- It was observed that the students did not read the explanations in the exhibition units.

- The students did not show interest in the mechanisms that they did not understand how they worked.

- They were not interested in mechanisms that they could not operate or thought they could not.

- They did not operate the mechanisms in accordance with their purpose or for learning purposes, they moved them unconsciously.

- The sculptures in different units in the exhibition area generally attracted attention and all the children touched the sculptures.

- The chemistry exhibition unit attracted attention with its closed form and historical structure. In general, it was wondered what was inside, but the content did not attract attention. Inside the apparatus, there is an informative video, experimental materials from the old period and a stool to watch the video.

- It was observed that the students who understood the purpose of the mechanism by operating it later showed interest in the explanation of the mechanism. Thus, the most memorable learning-by-experiment method was realized.

- It was observed that the students both showed more interest and enjoyed the device more while they were experiencing it with their friends.

\section{RESULTS}

Konya Science Center is a science center opened with the support of TUBITAK in Turkey. Therefore, the spatial design of the center and the themes that make up the content are thought to set examples for other science centers. In this regard, the educational environments of the science center are made up of exhibition units, education and culture units and planetarium. In this context, while the interior design of the exhibition units consists of mechanical and digital exhibition units, workshops and laboratories are focused on the use of technical equipment for the age group; in the planetarium, space and technology relationship is established with the dome-shaped curtain that creates the real sky environment. The most visited exhibition units in the exhibition venues are units describing advanced technology such as robots, space capsule, rocket design and launch, water transport systems, visual illusion and energy systems setups. The features of the educational environments of the Konya Science Center in terms of science and technology can be listed as follows:

- Using mechanical and digital setups in display areas

- Interactive exhibition units that can be tried by touching and playing.

- Organizing activities in workshops and laboratories within the scope of technology, science, robot and design activities

- Providing technical equipment that enhances creativity and imagination by arousing visitors' curiosity in fields such as mathematics, technology, engineering, space sciences and humanities.

- Nature and space themed screenings projected on the dome-shaped curtain, which is quite similar to the real sky, in the planetarium.

- Supporting interactive technological exhibition units such as water systems, optics, space technologies, robots, material technology, natural events, energy systems in the exhibition areas, using color light and different materials and increasing their appeal.

Students were observed in the Sultans of Science exhibition area, which is the sub-study area. In line with these observations, the results are as follows:

- It is observed that the entrance and exit of the sultans of science exhibition area are different and cannot be perceived by the visitors. For this reason, the entrance gate was indicated by placing a direction sign by the center.

- The exhibition units are not placed according to a certain setup in the Sultans of Science Exhibition Area. When users enter the exhibition area for the first time, they experience orientation problems for a while. 
- In the exhibition units, the boards containing written information about the purpose of use and the inventor of the device were not read by the students. They unconsciously used mechanical tools without knowing about the mechanisms. This situation has revealed that the information about the exhibition unit for the 1013 age group is insufficient. In addition, they did not show interest in the mechanisms that they did not understand the purpose of use because they did not read. Accordingly, the following general evaluations can be made regarding the design decisions of the educational environments of Science Centers.

- Exhibition areas, which are the focal point, should be brought to the fore.

- In the exhibition areas separated according to the themes, the space designs should be arranged according to the theme, to strengthen the perceptions of the mechanisms and increase the attractiveness. It is recommended to work with interior architects in this regard.

- The physical space of each exhibition unit in the exhibition areas should be differentiated according to the subject it contains, and its attractiveness should be increased. Thus, it can be easier for users entering the exhibition area to be directed according to their interests.

o In the exhibition areas, the circulation areas and the areas where the exhibition units are located can be made more dynamic and interesting with the difference in the materials to be used on the floor and the lighting suitable for the content of the unit.

o It may be recommended to use lightweight divider systems unique to each arrangement, instead of uniform information boards, especially in exhibition units. Illumination of the unit can be customized by hiding the lighting mechanism of the exhibition unit in these panels.

- Exhibition areas should be designed taking into account the spatial perception characteristics of children aged 10-13, who are the focus user group, and written information should be avoided as much as possible. - Exhibition areas with similar themes should be positioned in relation to each other to provide a wider perspective to the visitors.

o By associating the Sultans of Science exhibition area with the new horizons exhibition area, a link can be established between past and present inventions. In order to achieve this, connection routes can be set up for visitors to discover for themselves.

- Science and art-themed open-access playgrounds for preschool children can be added to the exhibition areas.

- For students, interactive exhibition units that can be tried by touching and playing between space and technology themed exhibition areas in science centers are among the places that make the biggest contribution in terms of informal education.

\section{CONFLICTS OF INTEREST}

No conflict of interest was declared by the authors.

\section{ACKNOWLEDGE}

This article has been produced from the master's thesis named "Konya Bilim Merkezinin Iç Mekan Tasarımının Kullanıcıları Üzerindeki Etkisi" completed in the Institute of Graduate School of Natural and Applied Sciences, Karadeniz Technical University. We thank to Furkan TOPAL, Merve ERTEN and Merve ÖKSÜZ, students of interior architecture at Konya Selcuk University, who helped during the observation phase of the study.

\section{REFERENCES}

[1] Ünalan, Z., Bilim Merkezleri, 525, Journal of Science and Technology, 30-41, (2011).

[2] Kurtuluş, A., "İnformal Öğrenme Ortamı Pi Günü: Büyük Risk Yarışması Örneği”, Journal of Research in Education and Teaching, 4(1): 107-116, (2015).

[3] Braund and Reiss, Towards a more authentic science curriculum:the contribution of out-of-school learning, http://discovery.ucl.ac.uk/10000454/1/Reiss2006Towards1373.pdf. Access date: 21.03. 2018 
[4] Atal, D., Koçak Usluel, Y., "İlköğretim Öğrencilerinin Okul İçinde ve Dışında Teknoloji Kullanımları", Hacettepe University Journal of Education, 41: 24-35, (2011).

[5] Cole, M., Scribner, S., "The cognitive consequences of education: some empirical evidence and theorietical misgivings", American Association for the Advancement of Science, Research Coate, 182: 553-559, (1973).

[6] İnce, M. C., "İnformal Öğrenme Ortamlarının Öğrencilerin Fen-Teknoloji-Toplum-Çevre İlişkisini Anlamalarına Etkisi”, MSc. Thesis, Yıldız Technical University, Graduate School of Natural and Applied Sciences, İstanbul, 23, (2017).

[7] Yılmaz, G., "Çocukta Mekan Algısının Gelişiminde Masalın Etkisi/Önemi”, MSc Thesis, Dokuz Eylül University, Graduate School of Natural and Applied Sciences, İzmir, (2010).

[8] Sturm, H., Bogner, F.X., "Learning at Workstations in Two Different Environments: A Museum and a Classroom", Studies in Educational Evaluation, 36: 14-19, (2010).

[9] Bozdoğan, A.E., "Okul Dışı Çevrelere Eğitim Amaçlı Gezi Düzenleyebilme Özyeterlik İnancı Ölçeğinin Geliştirilmesi”, Journal of Theoretical Educational Science, 9(1): 111-129, (2016).

[10] Karadeniz, C., "Dünyada Çocuk Müzeleri ile Bilim, Teknoloji ve Keşif Merkezlerinin İncelenmesi ve Türkiye İçin Bir Çocuk Müzesi Modeli Oluşturulması", MSc. Thesis, Ankara University, Graduate School of Social Sciences, Ankara, (2009).

[11] Bozdoğan, A.E., Yalçın, N., "Bilim Merkezlerinin İlköğretim Öğrencilerinin Fene Karşı İlgi Düzeylerinin Değişmesine ve Akademik Başarısına Etkisi: Enerji Parkı”, Ege Journal of Education, 2(7): 95-114, (2006).

[12] Aktekin, S., "Müze Uzmanlarının, Okulların Eğitim Amaçlı Müze Ziyaretlerine İlişkin Görüşleri”, Ahi Evran University Journal of Kırşehir Education Faculty, 9(2): 103-111, (2008).

[13] Ertaş, H., Şen, A.İ., Parmaksızoğlu, A., “Okul Dış1 Bilimsel Etkinliklerin 9. Sınıf Öğrencilerinin Enerji Konusunu Günlük Hayatla İlişkilendirme Düzeyine Etkisi”, Necatibey Faculty of Education Electronic Journal of Science and Mathematics Education, 5(2): 178-198, (2011).

[14] Tatar, N., Bağrıyanık, K.E., "Fen ve Teknoloji Dersi Öğretmenlerinin Okul Dışı Eğitime Yönelik Görüşleri”, http://www.ilkogretimonline.org.tr/index.php/io/article/view/1453/1309, (2019).

[15] Sözer, Y., "Sınıf İçi Öğretmenleri Destekleyen Okul Dışı Aktif Öğrenmeler: Bir Meta-Sentez Çalı̧̧ması", Ph.D Thesis, Dicle University, Graduate School of Educational Sciences, Diyarbakır, (2015).

[16] https://www.urlaubsheld.de/magazin/one-way-weltreise-in-die-urania-berlin. Access date: 21.07.2019

[17] Öz, R., "Araştırma ve Sorgulamaya Dayalı Etkinliklerle Desteklenmiş Bilim Merkezi Uygulamalarının 7. Sınıf Öğrencilerinin Akademik Başarılarına, Bilim Okuryazarlıklarına ve Sorgulayıı Düşünme Becerilerine Etkisi”, MSc. Thesis, Marmara University, Graduate School of Educational Sciences, Istanbul, (2015).

[18] Ok, Z., "Konya Bilim Merkezinde Gerçekleştirilen Atölye Çalışmalarının İlkokul ve Ortaokul Öğrencileri Tarafından Değerlendirilmesi”, MSc. Thesis, Necmettin Erbakan University, Graduate School of Educational Sciences, Konya, (2018). 
[19] https://bilimmerkezleri.tubitak.gov.tr/Upload/SingleFile/Dosya-563-258.pdf. Access date: 10.01.2019

[20] http://www.fezagurseybilimmerkezi.com/. Access date: 10.01.2019

[21] http://bayrampasabilimmerkezi.com/laboratuvarlar/. Access date: 10.01.2019

[22] http://mtbm.bornova.bel.tr/. Access date: 10.01.2019

[23] http://gezegenevi27.com.tr/. Access date: 10.01.2019

[24] http://www.eskisehirbilimdeneymerkezi.com/. Access date: 10.01.2019

[25] Erdoğan, S., “Konya Bilim Merkezi”, Mimaran, 9(12): 52-61, (2015).

[26] https://www.kbm.org.tr/hakkimizda. Access date: 10.01.2019

[27] http://www.bursabilimmerkezi.org/. Access date: 10.01.2019

[28] http://kocaelibilimmerkezi.com/hakkimizda. Access date: 15.01.2019

[29] http://www.elazigbilimmerkezi.com/resimler.html. Access date: 15.01.2019

[30] https://www.kayseri.bel.tr/haberler/kayseri-bilim-merkezi-bilimin-merkezinde. Access date: 15.01.2019

[31] Malçok, K., "Bilim Merkezlerinde Sürdürülebilir İç Mekan Kriterleri; Konya Bilim Merkezi", MSc. Thesis, Selçuk University-Hacettepe University, Graduate School of Social Sciences, Konya, 29, (2018).

[32] Burkut, E., "Bilim Merkezlerinin Mekansal Tasarım-Kullanım Bağlamında İncelenmesi: Konya Bilim Merkezi Örneği”, International Green Capitals Congress, Konya, 1018-1028, (2018).

[33] https://gezicini.com/konya-bilim-merkezi/. Access date: 15.01.2019

[34] Sırtkaya Uzun, A., "Konya Bilim Merkezinin İç Mekan Tasarımının Kullanıcıları Üzerindeki Etkisi”, MSc. Thesis, Karadeniz Technical University, Graduate School of Natural and Applied Sciences, Trabzon, (2019).

[35] https://www.kbm.org.tr/Etkinlikler/Tasarim-Atolyesi/913bf5ce-cf47-4382-b61e-c25592999c7a/ fa487941-8157-e511-80c4-005056954ffa. Access date: 07.03.2019

[36] https://www.kbm.org.tr/Etkinlikler/Matematik-ve-Teknoloji-Laboratuvari/1e8079fb-b498-4eff89f9-4facf6499b6c/fa487941-8157-e511-80c4-005056954ffa. Access date: 07.03.2019

[37] https://www.kbm.org.tr/Etkinlikler/Fizik-Laboratuvari/78a89f5f-3830-49e3-aec7-9cd7c2ceaff6/ fa487941-8157-e511-80c4-005056954ffa. Access date: 07.03.2019 